Editorial

\title{
Prosthesis and infection: problem in bionics era
}

\section{Editorial}

In the present day, application of bionics technology in medicine is acceptable for its advantage. The medical prosthesis can be developed based on bionics technology and becomes the important tool for management of the problem with organ loss or damage. While the use of prosthesis is useful, the complication due to improper and poorly controlled use of bionics can be expected. If there is no proper control in quality of usage, unwanted adverse outcome might be expected. An important problem that should be mentioned is the infection. This problem is usually relating to the poor sanitation control of medical prosthesis usage. As noted by Veerachamy et al., ${ }^{1}$ the bacterial adherence and biofilm formation on medical implants is an important problem to be considered. ${ }^{1}$ The prevention is necessary and the preventive measures start from good biomaterial selection, good prosthetic design and good infection control regarding any procedures dealing with medical prosthesis..$^{2-3}$ Antibiotic prophylaxis for the patient undergoing prosthesis surgery is also recommended. ${ }^{4}$ Nevertheless, the efficacy of the antibiotic prophylaxis in this issue is still controversial. ${ }^{5}$

As noted by Dryden, "While prosthetic joint infection (PJI) rates are generally low, infection can be catastrophic for the patient and hence prevention of infection is critical." In animal model trial of bionic prosthesis, the infection is an important complication of prosthesis implantation. ${ }^{7}$ In human, if the infection occurs after prosthesis implantation at the vital organ, the most unwanted complication is death. ${ }^{8}$ In case that there is a suspicious for infection relating to prosthesis contamination, the removal of the prosthesis might be necessary. ${ }^{9}$ The improvement of the biomaterial for construction of prosthesis can help improve the quality of prosthesis and reduce possibility of infection. ${ }^{10}$ The sanitation management by good infection control is required for any dealing with medical prosthesis. The total quality management for using bionic prosthesis has to start from good design, good clinical use and good care after medical implantation.

\section{Acknowledgments}

None.

\section{Conflict of interest}

The authors declare that there are no conflicts of interest.

\section{Funding details}

None.

\author{
Volume 3 Issue 4 - 2019
}

Viroj Wiwanitkit

Adjunct professor, Joseph Ayobabalola University, Nigeria

Correspondence: Viroj Wiwanitkit, Adjunct professor, Joseph Ayobabalola University, Ikeji Arakeji, Nigeria,

Email wviroj@yahoo.com

Received: July 22, 2019 | Published: August 19, 2019

\section{References}

1. Veerachamy S, Yarlagadda T, Manivasagam G, et al. Bacterial adherence and biofilm formation on medical implants: a review. Proc Inst Mech Eng H. 2014;228(10):1083-1099.

2. Pavithra D, Doble M. Biofilm formation, bacterial adhesion and host response on polymeric implants--issues and prevention. Biomed Mater. 2008;3(3):034003.

3. Reid G. Bacterial colonization of prosthetic devices and measures to prevent infection. New Horiz. 1998;6(2 Suppl):S58-63.

4. DeFroda SF, Lamin E, Gil JA, et al. Antibiotic Prophylaxis for Patients with a History of Total Joint Replacement. J Am Board Fam Med. 2016;29(4):500-507.

5. Colterjohn T, de Beer J, Petruccelli D, et al. Antibiotic prophylaxis for dental procedures at risk of causing bacteremia among post-total joint arthroplasty patients: a survey of Canadian orthopaedic surgeons and dental surgeons. J Arthroplasty. 2014;29(6):1091-1097.

6. Dryden M. Prosthetic joint infection: managing infection in a bionic era. $J$ Antimicrob Chemother. 2014;69 Suppl 1:i3-4.

7. Abbott CJ, Nayagam DAX, Luu CD, et al. Safety Studies for a 44-Channel Suprachoroidal Retinal Prosthesis: A Chronic Passive Study. Invest Ophthalmol Vis Sci. 2018;59(3):1410-1424.

8. Schalij MJ. The bionic heart patient: care about aftercare. Ned Tijdschr Geneeskd. 2013;157(51):A7059.

9. Wouthuyzen-Bakker M, Sebillotte M, Lomas J, et al. Timing of implantremoval in late acute periprosthetic joint infection: A multicenter observational study. J Infect. 2019;79(3):199-205.

10. Großhauser J, Reiter K, Große Siestrup C, et al. Bionic approach for the prevention of exit-site infections of percutaneous devices. Biomed Tech (Berl). 2015;60(3):225-233. 